\title{
Efektivitas Teknik Prompting dan Positive Reinforcement untuk Meningkatkan Frekuensi Kontak Mata pada Anak Prasekolah dengan Autisme
}

\section{The Effectiveness of Prompting and Positive Reinforcement Technique to Increase Eye Contact Behavior for Preschool Children with Autism}

\author{
Anita Carolina Hendarko ${ }^{1}$, Ike Anggraika ${ }^{2}$ \\ ${ }^{1,2}$ Magister Profesi Psikologi Klinis Anak, Fakultas Psikologi, Universitas Indonesia \\ Email: anita.carolina.h@gmail.com
}

KATA KUNCI KEYWORDS

ABSTRAK

ABSTRACT
Autisme, modifikasi perilaku, prompting, kontak mata

Austism, behavioral modification, prompting, eye contact

Anak-anak dengan autisme menunjukkan defisit dalam keterampilan komunikasi dan interaksi sosial, salah satunya adalah kurangnya kontak mata. Tujuan penelitian ini adalah untuk meningkatkan frekuensi kontak mata pada anak usia pra sekolah dengan autisme dengan menggunakan teknik prompting dan positive reinforcement. Penelitian ini menggunakan single case experimental A-B design. Partisipan adalah seorang anak perempuan berusia 4 tahun dengan diagnosa ASD level moderate. Teknik pengumpulan data melalui observasi frekuensi kontak mata setelah subjek dipanggil namanya. Analisis data dilihat dengan membandingkan frekuensi kontak mata sebelum dan sesudah intervensi dilakukan. Hasil penelitian menunjukkan adanya peningkatan frekuensi kontak mata yang signifikan pada partisipan, dari 5\% sebelum intervensi menjadi $75 \%$ setelah intervensi berakhir dan bertahan menjadi $80 \%$ saat follow-up. Untuk penelitian selanjutnya, perlu dipertimbangkan beberapa hal, yaitu pemilihan aktivitas dan reinforcement dan keterlibatan orangtua merupakan faktor pendukung program pelatihan pada anak.

Lack of eye contact behavior is an early predictor of deficits in joint attention for children with autism. The purpose of this research is to assess effectiveness of prompting and positive reinforcement technique to increase eye contact behavior in preschool children with autism. This research use single-case experimental A-B design. Subject of this research is a 4 years old girl with moderate autisme. Data collection technique trough observation of the frequency of eye contact after subject is called by her name. Data analysis trough comparition of frequency of eye contact before and after intervention. The result of this research shows a significant increase in the frequency of eye contact, from $5 \%$ before intervention become $75 \%$ during intervention, and $80 \%$ during follow-up. In future research, it is necessary to consider several things: selection of activities and reinforcement and parental involvement is important factors supporting the training program for children. 


\section{PENDAHULUAN}

Menurut Mangunsong (2009), anak berkebutuhan khusus (ABK) adalah anak yang memiliki karakteristik yang berbeda dari anak seusianya pada umumnya pada beberapa dimensi kehidupan, seperti fisik, psikologis, kognitif, dan sosial. Hal tersebut berdampak pada kesulitan anak dalam berbagai aspek kehidupan, seperti sosial, personal, dan pendidikan. Terdapat berbagai macam jenis anak berkebutuhan khusus, salah satunya adalah Autism Sprectrum Disorder (ASD).

Menurut data dari World Health Organization (WHO, 2018) dan The Center of Disease Control and Prevention (CDC) (Autism Speak, 2018) pada tahun 2018, prevalensi anak dengan autisme di seluruh dunia meningkat drastis, yaitu 1 berbanding 160. Di Indonesia, pada tahun 2015 satu berbanding 250 anak mengalami Autism Spectrum Disorder (ASD) dan terdapat kurang lebih 12.800 anak dengan autisme.

Autism Spectrum Disorder
merupakan gangguan neurodevelopmental yang ditandai dengan gangguan dalam komunikasi sosial dan interaksi serta adanya perilaku yang terbatas dan berulang. Hal tersebut meliputi keterbatasan dalam hubungan sosial-emosional yang timbal balik, keterbatasan dalam menunjukkan komunikasi verbal maupun nonverbal untuk interaksi sosial, dan keterbatasan dalam membangun, mempertahankan, dan memahami sebuah hubungan. Selain hal tersebut, terdapat kriteria lain yang dialami oleh anak-anak dengan autisme, yaitu pola perilaku, minat, atau aktivitas yang terbatas dan berulang; yaitu: (i) gerakan motor, penggunaan benda, atau kata-kata yang berulang; (ii) keinginan untuk melakukan atau mendapatkan hal yang sama terus menerus dan tidak fleksibel; dan (iii) minat yang sangat terbatas dan tidak bisa berubah dengan intensitas dan fokus yang tidak normal (APA, 2013).

Menurut Dawson, Abbot, Osterling, Munson, Estes, \& Liaw (2004). anak-anak dengan autisme memiliki keterbatasan dan kesulitan dalam atensi sosial, yaitu kesulitan dalam melakukan joint attention. Joint attention dan atensi sosial ini memiliki peran yang sangat penting dalam interaksi sosial. Rendahnya kemampuan untuk atensi sosial pada anak dengan ASD akan menghambat pemahaman mereka terhadap tindakan orang lain (Begeer, Rieffe, Termorgt, \& Stockmann, 2006).

Mash dan Wolfe

(2010)

menjelaskan bahwa anak dengan autisme memiliki kesulitan dan keterbatasan dalam berinteraksi dengan orang lain, bahkan. Mereka menunjukkan defisit keterampilan sosial yang krusial pada usia emas (1-5 tahun). Misalnya terbatasnya kemampuan komunikasi timbal balik dalam berinteraksi sosial, kontak mata terbatas, kurangnya minat untuk berinteraksi dengan orang lain, sulit mengembangkan permainan imajinatif, dan gagal berbagi kesenangan dan minat dengan orang lain.

Pada anak pra sekolah dengan autisme, mereka biasanya sangat jarang menampilkan perilaku kontak mata. Hal ini menyebabkan mereka kesulitan dalam merespon interaksi dari orang lain. Seiring bertambahnya usia biasanya mereka kesulitan dalam menginisiasi dan mempertahankan interaksi dengan orang lain (Kennedy \& Shawn, 2008).

Perilaku kontak mata merupakan pengkoordinasian atensi visual kepada orang lain. Perilaku kontak mata merupakan perilaku memalingkan kepala dan wajah ke orang yang memanggil, melihat ke arah mata orang yang memanggil, baik disertai dengan pembicaraan dan kegiatan ataupun tidak disertai pembicaraan dan kegiatan. Kontak mata merupakan bentuk atensi sosial yang paling mendasar. Maka dari itu, pelatihan kontak mata pada anak dengan autism dapat membantu mereka dalam melakukan atensi dan interaksi sosial (Carbone, O'Brien, Sweeney-Kerwin, \& Albert, 2013; Kennedy \& Shawn, 2008).

Menurut Carbone, dkk (2013), kontak mata merupakan aktivitas sosial yang paling mendasar dan penting karena kontak mata berfungsi untuk mengatur tatap 
muka pada masing-masing anak dalam berinteraksi sosial. Kontak mata yang baik akan mendukung interaksi sosial yang baik, sebaliknya, kontak mata yang buruk berdampak pada kurangnya interaksi sosial. Selain itu, kontak mata merupakan salah satu aspek penting terhadap peningkatan penguasaan bahasa pada anak.

Berdasarkan hal tersebut, pelatihan kontak mata penting dilakukan pada anak dengan autisme sejak usia dini. Kennedy dan Shawn (2008) menjelaskan bahwa pelatihan kontak mata pada anak pra sekolah dengan autisme dapat menjadi keterampilan dasar sebelum anak menerima terapi-terapi komunikasi yang lainnya. Pelatihan kontak mata pada anak pra sekolah juga dapat membantu anak menampilkan perilaku dasar dalam berinteraksi dengan orang lain. Hal ini juga dapat membantu mempersiapkan anak pra sekolah dengan autisme untuk bisa melakukan interaksi sosial dengan teman sebayanya saat mulai memasuki usia sekolah.

Terdapat beberapa intervensi yang dapat dilakukan untuk membantu meningkatkan perilaku kontak mata dan joint attention pada anak dengan autisme. Misalnya, intervensi berbasis pendekatan kognitif dan perkembangan, seperti Relationship Development Intervention (RDI) dan Floor-Timel DIR. Akan tetapi masih sedikit penelitian yang menggunakan RDI dan Floor-time dan kurang efektif untuk digeneralisasikan kepada orangtua maupun pengasuh dalam setting sehari-hari (Gutstein, Burgess, \& Montfort, 2007).

Intervensi lainnya yang sering digunakan dalam meningkatkan kemampuan interaksi dan komunikasi pada anak dengan autism adalah pelatihan imitasi berbicara (Speech Imitation Training), yang mengajarkan anak dengan ASD berbicara dengan cara meniru berbagai macam produksi suara dan kata yang diucapkan terapis. Akan tetapi, program terapi ini mengharuskan anak untuk memiliki keterampilan seperti atensi, duduk dengan benar, kontak mata, imitasi oral dan motorik. Anak harus diajarkan keterampilan-keterampilan tersebut terlebih dahulu baru kemudian diajarkan keterampilan untuk berkomunikasi dengan orang lain (Bondy\& Frost, 2001).

Salah satu intervensi yang efektif digunakan untuk anak dengan autisme adalah intervensi berbasis pendekatan Applied Behavior Analysis (ABA), yaitu pelatihan yang berfokus pada hubungan sistematis antara tingkah laku dengan lingkungan, anteseden (peristiwa yang terjadi sebelum munculnya tingkah laku) dan konsekuensinya (peristiwa setelah munculnya tingkah laku).

Metode ABA menggunakan prinsipprinsip dasar pembelajaran perilaku, seperti shaping, chaining, dan prompt, serta transfer of stimulus control. Prompt adalah kejadian yang membantu munculnya sebuah respon. Sementara transfer of stimulus control (fading) merupakan teknik pengurangan prompt secara bertahap (Kazdin, 2013). Di samping itu, pada penelitian ini peneliti juga menggunakan prinsip positive reinforcement, yaitu social reinforcer dan consumable reinforcer jika anak berhasil menampilkan perilaku kontak mata. Menurut Miltenberger (2012) penggunaan prompting dan transfer of stimulus control (fading) efektif dilakukan untuk meningkatkan perilaku kontak mata pada anak dengan autisme.

Lindgren dan Doobay (2011) menjelaskan bahwa pemberian intervensi dengan prinsip-prinsip pembelajaran perilaku tersebut mudah diterapkan oleh orangtua maupun pengasuh anak dengan autisme, sehingga dapat digeneralisasikan dalam berbagai setting kehidupan anak.

Pada penelitian ini, perilaku kontak mata mencakup perilaku memalingkan kepala dan wajah ke orang yang memanggil, melihat ke arah mata orang tersebut, baik disertai dengan pembicaraan dan kegiatan ataupun tidak disertai pembicaraan dan kegiatan. Sementara itu, perilaku yang tidak termasuk kontak mata dalam program intervensi ini adalah melirik/ melakukan kontak mata tanpa 
dipanggil dan atau melakukan kontak mata dengan inisiatif sendiri, misalnya ketika menunjukkan sesuatu.

Tujuan dari penelitian ini adalah mengukur efektitivitas teknik modifikasi perilaku, yaitu prompting dan positive reinforcement untuk meningkatkan frekuensi kontak mata pada anak dengan autism. Di samping itu perancang program juga menggunakan teknik fading untuk mengurangi prompt secara bertahap dan menggunakan positive reinforcement untuk membantu anak dalam melakukan kontak mata. Selain itu, diharapkan anak dapat melakukan generalisasi terhadap perilaku kontak mata, seperti melakukan kontak mata setelah namanya dipanggil dengan orang lain dan ketika diajak berbicara tanpa memperoleh bimbingan.

\section{METODE PENELITIAN}

\section{Desain Penelitian}

Desain penelitian ini adalah single subject $A-B$ design dengan subjek satu $(\mathrm{N}=1)$. Penelitian ini menggunakan one group pretest-posttsest, yang bertujuan untuk melihat perbandingan dengan mengukur skor partisipan sebelum diberikan pelatihan dan setelah diberikan pelatihan.

\section{Partisipan}

Partisipan dalam penelitian ini adalah anak usia prasekolah dengan diagnosa Autism Sprectrum Didorder. Partisipan berjumlah satu dengan inisial A dan berusia 4 tahun 4 bulan. Partisipan merupakan anak yang diberikan diagnosa ASD dengan tingkat keparahan moderate disertai dengan language impairment.

Berdasarkan hasil pemeriksaan psikologis yang dilakukan, ditemukan ciriciri adanya keterbatasan dalam interaksi sosial dan berkomunikasi serta beberapa perilaku terbatas dan ketertarikan pada stimulus sensori yang tidak biasa pada A.

Saat ini A masih memiliki kosa kata yang sangat terbatas. Selain itu ia sering berbicara sendiri dengan mengoceh tidak jelas dan tidak memiliki arti. Kemampuan bahasa nonverbal A juga masih terbatas. Ia jarang menampilkan ekspresi emosinya dan menggunakan gestur untuk berinteraksi dengan orang lain. Saat diajak berinteraksi dan berkomunikasi A sering tidak merespon, terutama jika ia sedang asyik sendiri. Ia juga tidak menunjukkan adanya keinginan untuk berinteraksi dengan orang lain. Selain itu, kontak mata A masih sangat terbatas. A tidak dapat menoleh dan merespon ketika ia dipanggil namanya. Ia juga belum bisa diajak berinteraksi dan belum mampu memperhatikan instruksi yang diberikan.

Di samping itu A menampilkan pola perilaku yang terbatas, berulang-ulang (repetitif), dan tanpa tujuan. A juga memiliki ketertarikan yang tidak biasa pada aspek sensori (suara). Hingga saat ini, A belum pernah diberi terapi.

\section{Instrumen Penelitian}

Instrumen penelitian yang digunakan yaitu observasi dan wawancara. Indikator observasi pada penelitian ini adalah menggunakan observasi langsung dengan menghitung frekuensi kontak mata yang ditampilkan A setelah 1-3 detik dipanggil namanya dalam setiap sesi pengamatan. Satu sesi pengamatan terdiri 10 kali percobaan pemanggilan nama dengan rentang waktu 2 menit.

Selanjutnya, wawancara dilakukan kepada ibu subjek untuk membantu mengetahui perilaku kontak mata pada subjek sehari-hari.

Indikator perilaku kontak mata pada penelitian ini adalah mencakup perilaku memalingkan kepala dan wajah ke orang yang memanggil, melihat ke arah mata orang tersebut, baik disertai dengan pembicaraan dan kegiatan maupun tidak disertai pembicaraan dan kegiatan ketika nama anak dipanggil (maksimal sebanyak tiga kali panggilan), dengan waktu reaksi 13 detik. Sementara itu, perilaku yang tidak termasuk kontak mata dalam program intervensi ini adalah melirik/ melakukan kontak mata tanpa dipanggil dan atau 
melakukan kontak mata dengan inisiatif sendiri (misalnya ketika menunjukkan sesuatu), dan menatap ke arah orang yang memanggil dengan waktu reaksi lebih dari 3 detik setelah namanya dipanggil.

\section{Analisa Data}

Analisis data dilakukan dengan teknik statistik deskriptif menggunakan grafik. Analisis data didapatkan dengan membandingkan frekuensi kontak mata sebelum diberikan intervensi dan setelah diberikan intervensi.

\section{Prosedur Penelitian}

Prosedur penelitian pada penelitian ini terbagi menjadi tiga, yaitu tahap persiapan, tahap intervensi, dan tahap follow-up.

Pertama, tahap persiapan. Sebelum menentukan prosedur penelitian, peneliti terlebih dahulu melakukan need assessment melalui wawancara orangtua dan observasi pada anak. Hasil need assessment menunjukkan kurangnya perilaku kontak mata pada anak. Selain itu need assessment juga dilakukan untuk mengetahui aktivitas dan jenis reinforcement yang disukai anak untuk digunakan selama intervensi. Kemudian peneliti melakukan baseline sebanyak dua pertemuan (4 sesi). Setiap sesi berlangsung selama 20-30 menit.

Kedua, tahap intervensi. Program intervensi dilaksanakan selama 10 kali pertemuan, di mana tiap pertemuan terdiri dari dua sesi. Setiap sesi berlangsung selama 20-30 menit.

Terakhir, tahap follow-up dilakukan sebanyak satu kali pertemuan (2 sesi). Tahap follow-up dilakukan setelah 2 minggu program selesai dilaksanakan untuk menentukan apakah perubahan yang dicapai selama program dapat dipertahankan setelah program usai.

\section{Program Intervensi}

Program modifikasi perilaku pada penelitian ini menggunakan teknik prompt verbal dan prompt fisik untuk membantu meningkatkan frekuensi kontak mata pada A. Ketika respon yang tepat sudah dilakukan oleh anak, maka prompts sedikit demi sedikit secara bertahap akan dikurangi dan dihilangkan (transfer of stimulus control/ fading). Selain itu, program intervensi pada penelitian ini ditambah dengan pemberian positive reinforcement berupa social reinforcers (memberikan pujian, acungan empol, belaian, tepuk tangan, dan lain sebagainya) dan consumable reinforcers (barang-barang yang disukai anak, seperti makanan dan mainan). Reinforcers tersebut diberikan setiap kali anak berhasil menampilkan perilaku kontak mata.

Setiap sesi intervensi dilakukan sebanyak 10 kali trial memanggil nama $\mathrm{A}$ sebanyak 1-3 kali dengan rentang antar trial sekitar 2 menit. Frekuensi kontak mata yang dihitung dalam penelitian ini adalah perilaku kontak mata yang dilakukan A dalam waktu 1-3 detik setelah namanya dipanggil. Program dikatakan berhasil apabila subjek dapat menunjukkan peningkatan frekuensi perilaku kontak mata minimal 50\% dari hasil baseline. Berikut ini adalah uraian tahapan, sesi, dan teknik yang digunakan pada program pelatihan ini:

Tabel 1.

Tahapan Program Pelatihan

\begin{tabular}{ccl}
\hline Tahap & Jumlah Sesi (@Sesi: 30 menit) & \multicolumn{1}{c}{ Teknik } \\
\hline Baseline & 4 & $*$ Jumlah trial: 10, waktu reaksi: $1-3$ detik \\
& 2 & *Setting: aktivitas bermain \\
Tahap 1a & * Jumlah trial: 10, waktu reaksi: $1-3$ detik \\
& *Prompt: verbal \& fisik \\
& *Positive reinforcement: pujian dan makanan \\
& *Setting: aktivitas bermain
\end{tabular}

Tahap 1b 


\begin{tabular}{|c|c|c|}
\hline Tahap & Jumlah Sesi (@Sesi: 30 menit) & Teknik \\
\hline Tahap 1c & 2 & \\
\hline Tahap 2a & 2 & $\begin{array}{l}\text { * Jumlah trial: } 10 \text {, waktu reaksi: } 1-3 \text { detik } \\
\text { *Prompt: verbal } \\
\text { *Positive reinforcement: pujian dan makanan } \\
\text { * Setting: aktivitas bermain }\end{array}$ \\
\hline Tahap 2b & 2 & \\
\hline Tahap 2c & 2 & \\
\hline Tahap 3a & 2 & $\begin{array}{l}\text { * Jumlah trial: } 10 \text {, waktu reaksi: } 1-3 \text { detik } \\
\text { * Prompt: delay prompt dengan jeda } 5 \text { detik. } \\
\text { *Positive reinforcement: pujian dan makanan } \\
\text { *Setting: aktivitas bermain }\end{array}$ \\
\hline Tahap 3b & 2 & \\
\hline Tahap 4a & 2 & $\begin{array}{l}\text { * Jumlah trial: } 10 \text {, waktu reaksi: } 1-3 \text { detik } \\
\text { * Positive reinforcement: pujian dan makanan } \\
\text { *Setting: aktivitas bermain }\end{array}$ \\
\hline Tahap 4b & 2 & \\
\hline Follow-up & 2 & $\begin{array}{l}\text { * Jumlah trial: } 10, \text { waktu reaksi: } 1-3 \text { detik } \\
\text { * Setting: aktivitas bermain }\end{array}$ \\
\hline \multicolumn{2}{|c|}{ ANALISIS \& HASIL } & $\begin{array}{l}\text { pelaksanaan intervensi, dan follow-up. } \\
\text { Frekuensi kontak mata yang dihitung dalam } \\
\text { penelitian ini adalah perilaku kontak mata }\end{array}$ \\
\hline ne : & Hasil frekuensi kontak mata A saat & detik setelah namanya dipanggil. \\
\hline
\end{tabular}
percobaan (rata-rata=5\%). Pada saat pengambilan baseline, A tidak terlihat merespon panggilan dari pemeriksa. Ia tidak melakukan kontak mata saat dipanggil namanya. Terkadang AG hanya menoleh ke arah pemeriksaan saat pemeriksa bermain namun ia tidak melakukan kontak mata langsung dengan pemeriksa yang mengajaknya bermain dan berinteraksi.

Setelah baseline, peneliti melakukan sesi intervensi sebanyak 20 sesi, di mana setiap pertemuan terdiri dari dua sesi. Selama pelaksanaan program, jadwal cukup rutin dilakukan karena Ibu selalu kooperatif dengan jadwal program intervensi. Meskipun demikian, terdapat beberapa hambatan dalam pelaksanaan program modifikasi ini, antara lain ibu tidak selalu bisa mendampingi sesi intervensi karena setiap kali pelaksanaan program adik AG selalu ikut dibawa sehingga ibu tidak fokus pada AG.

Berikut adalah frekuensi perilaku kontak mata pada A dibandingkan dengan jumlah pemberian prompt, selama baseline,

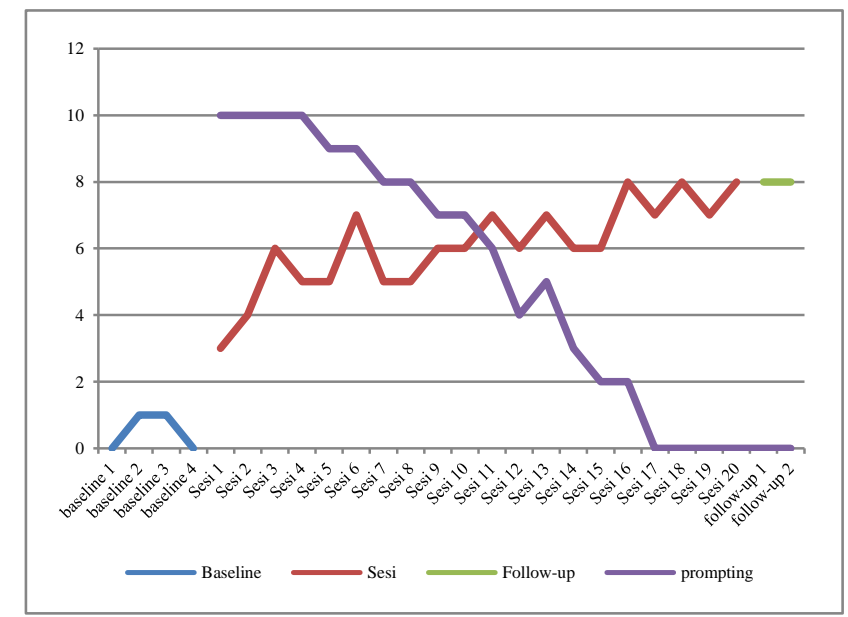

Gambar 1.

Grafik Frekuensi Kontak Mata

Berdasarkan grafik di atas, terlihat adanya peningkatan frekuensi perilaku kontak mata pada A, dari jumlah kontak mata sebanyak 0 atau 1 kali hingga menjadi 8 kali dalam satu sesi (10 kali percobaan). Hal tersebut menunjukkan bahwa teknik prompting dan positive reinforcement 
berhasil membantu anak dengan autism dalam meningkatkan perilaku kontak mata.

Meskipun demikian, pada sesi 7 dan 8, frekuensi perilaku kontak mata pada A mengalami penurunan. Hal ini dapat disebabkan adanya pengurangan pemberian prompt, dari prompt fisik dan prompt verbal menjadi hanya prompt verbal. Perilaku kembali mengalami peningkatan frekuensi pada pelaksanaan sesi 9. Selain itu, beberapa faktor lain seperti kondisi fisik A, pemberian aktivitas dan reinforcement yang sesuai untuk A, dan keikutsertaan ibu dalam melakukan program intervensi juga turut mempengaruhi frekuensi perilaku kontak pada pada A selama program intervensi dilakukan.

Jika dibandingkan dengan hasil baseline maka terlihat bahwa perilaku yang ditampilkan oleh AG pada baseline mengalami peningkatan setelah menggunakan teknik-teknik prompting pada modifikasi perilaku. Dapat dikatakan secara keseluruhan, terlihat adanya peningkatan perilaku kontak mata pada $\mathrm{AG}$ dari sesi 1 hingga sesi 20. Selain itu, pada grafik dapat terlihat adanya penurunan frekuensi pemberian prompt pada AG. Grafik menunjukkan bahwa jumlah pemberian prompt terus menurun dari sesi 1 hingga sesi ke 20.

Selain itu, setelah program intervensi dilakukan peneliti juga melakukan sesi follow-up dua minggu setelah intervensi selesai dilakukan. Sesi follow-up dilakukan untuk mengetahui apakah perilaku kontak mata pada A dapat bertahan atau tidak meskipun program pelatihan telah selesai dilakukan.

Tahap follow-up dilakukan selama satu kali pertemuan (dua sesi). Tahap follow-up dilakukan dengan metode yang sama dengan program intervensi sesi terakhir, yaitu memanggil A dan menghitung frekuensi kontak mata pada A setiap kali dipanggil tanpa bantuan sama sekali.

Pada saat pemberian intervensi di sesi-sesi awal A sering menampilkan perilaku tantrum, seperti menangis, memukul, dan menggigit. Ia juga sulit untuk memperhatikan dan diajak beraktivitas bersama peneliti. Akan tetapi, pada sesi-sesi berikutnya A terlihat lebih tenang dan kooperatif. Hingga di akhir sesi A sama sekali tidak menampilkan perilaku tantrum. Ia juga terlihat lebih tenang dan kooperatif ketika diajak beraktivitas bersama pemeriksa.

Selain itu, pelaksanan intervensi sedikit berbeda dari rencana awal. Awalnya, ibu diikut sertakan dalam pelatihan. Akan tetapi karena setiap kali pelatihan ibu selalu membawa adik A dan tidak bisa fokus dalam memberikan pelatihan pada A, maka ibu tidak diikutsertakan dalam program ini. Meskipun demikian, peneliti tetap memberikan pelatihan pada ibu. Selain itu, ibu juga diberikan pekerjaan rumah untuk terus melatih kontak mata A setiap kali beraktivitas pada A. Ibu selalu mengerjakan pekerjaan rumah tersebut dan juga melatihkan program kontak mata A pada pengasuh A di daycare.

Berikut perbandingan persentase frekuensi perilaku kontak mata yang ditampilkan anak saat baseline, intervensi, dan follow-up:

Gambar 2.

Perbandingan Hasil Intervensi

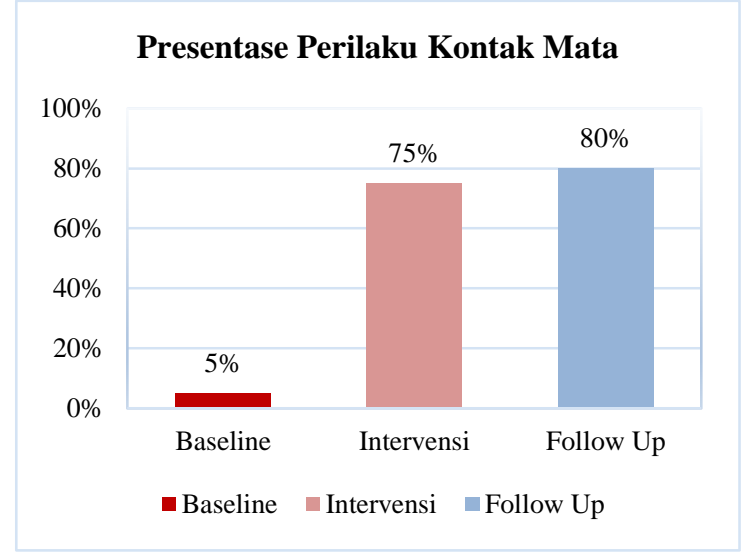

Berdasarkan grafik perbandingan terlihat bahwa perilaku yang ditampilkan oleh A pada baseline mengalami peningkatan setelah menggunakan teknikteknik prompting pada modifikasi perilaku. Frekuensi kontak mata AG yang awalnya 
hanya sebanyak 5\%, meningkat menjadi $75 \%$. Berdasarkan hasil follow-up juga diketahui bahwa kemampuan A dalam melakukan kontak mata bisa bertahan setelah program intervensi berakhir (frekuensi=80\%). Hal tersebut menunjukkan bahwa target keberhasilan program intervensi, yang awalnya mensyaratkan $50 \%$ perilaku muncul, dapat tercapai. Perilaku kontak mata yang hampir tidak muncul sebelum intervensi kini dapat ditampilkan oleh A, meskipun tanpa dibantu prompt.

Selain itu, selama follow-up peneliti juga melakukan observasi dan wawancara kepada orangtua mengenai efek program pelatihan kontak mata yang diberikan. Selama tahap follow-up, A terlihat lebih tenang dan atentif. Ia juga mau melakukan kontak mata ketika dipanggil namanya, baik oleh pemeriksa bahkan oleh orang lain (teman pemeriksa). A tidak terlihat menolak ketika dipanggil. Selain itu, ia tidak menampilkan perilaku tantrum. A juga terlihat lebih responsif dan beberapa kali tersenyum ketika diajak bernyanyi dan bermain oleh pemeriksa. Ibu juga menjelaskan hal yang sama dengan observasi dari pemeriksa. Menurut ibu, saat ini A sudah mampu menunjukkan kontak mata setiap kali namanya dipanggil. Ia juga terlihat lebih atentif dan tenang ketika diajak berinteraksi dengan orang lain.

Di samping itu, peneliti juga menghitung rata-rata waktu reaksi anak menampilkan perilaku kontak mata (1-3 detik) setelah namanya dipanggil pada setiap sesi intervensi (10 trial). Berikut ratarata waktu reaksi anak menampilkan

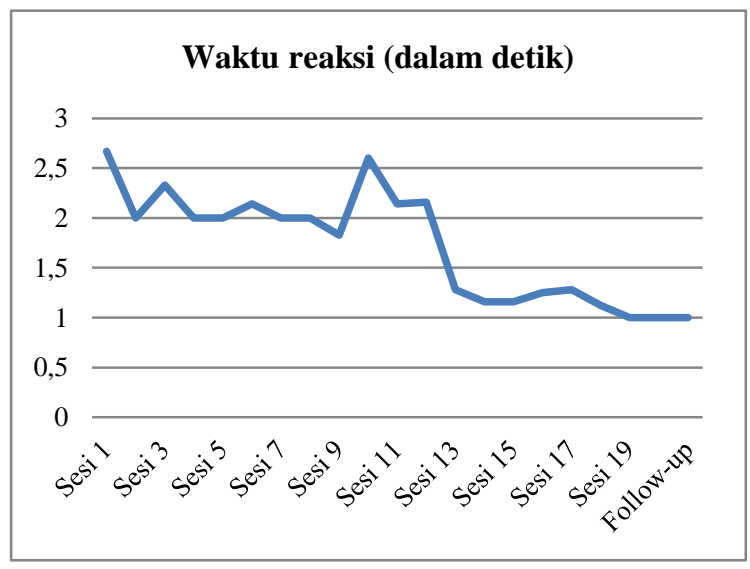

perilaku kontak mata pada setiap sesi:

Gambar 3.

Waktu Reaksi Anak Merepson

Berdasarkan grafik, dapat terlihat bahwa anak semakin cepat merespon ketika namanya dipanggil, dari rata-rata 2,67 detik pada sesi satu hingga menjadi 1 detik pada sesi terakhir dan follow-up. Hal ini menunjukkan bahwa program ini bukan hanya dapat meningkatkan frekuensi kontak mata, namun juga dapat mempercepat waktu reaksi anak dalam menampilkan perilaku kontak mata ketika namanya dipanggil.

\section{DISKUSI}

Hasil penelitian menunjukkan adanya peningkatan frekuensi perilaku kontak mata pada anak pra sekolah dengan Autisme menggunakan metode prompting dan positive reinforcement. Beberapa hal yang mempengaruhi keberhasilan penelitian ini adalah sebagai berikut:

1. Generalisasi program akan lebih baik jika jumlah responden lebih dari satu.

2. Keikutsertaan orangtua dalam program pelatihan dapat membantu peningkatan perilaku kontak mata pada anak. Selain itu, orangtua atau pengasuh juga dapat mengaplikasikan teknik pelatihan kontak mata di setting sehari-hari. Hal ini dapat membantu anak menampilkan perilaku kontak mata. Pada penelitian ini, orangtua tidak dapat ikut serta karena selama pelatihan berlangsung orangtua selalu mengajak adik dari subjek sehingga tidak mampu fokus pada subjek

3. Pemberian prompt fisik dan verbal harus dilakukan secara konsisten dan memperhatikan kenyamanan anak. Pemberian prompt yang konsisten dapat membantu anak menampilkan perilaku kontak mata dengan optimal.

4. Pemberian reinforcement yang tepat dan consumable reward yang disukai anak dapat membantu anak untuk menoleh ke arah pemeriksa. Misalnya, pada penelitian ini reward yang efektif bagi 
partisipan adalah makanan. Selain itu, peneliti juga melibatkan anak untuk terus menampilkan perilaku kontak mata pada saat ia memakan consumable reward yang diberikan pemeriksa. Hal ini membuat kontak mata pada anak bertahan lebih lama.

5. Aktivitas bersama dan permainan yang menarik untuk anak dapat memicu anak untuk melakukan kontak mata. Misalnya, makan, berjalan-jalan, dan menyanyi bersama dapat meningkatkan perilaku kontak mata dan respon interaksi pada anak Selain itu, melibatkan anak untuk melakukan aktivitas bersama yang disukai anak juga mampu meningkatkan perilaku kontak mata pada anak.

6. Kondisi fisik yang tidak fit dapat mempengaruhi perilaku kontak mata pada anak. Pada penelitian ini, pada sesi ke empat partisipan sedang dalam kondisi kesehatan yang kurang fit. Hal ini membuat ia susah untuk tenang, kooperatif, dan beberapa kali menangis. Karena hal tersebut, frekuensi kontak mata partisipan pada sesi ke empat sempat mengalami penurunan.

\section{SIMPULAN}

Berdasarkan data yang diperoleh, dapat disimpulkan bahwa program modifikasi perilaku dengan menggunakan teknik prompting yang dilakukan oleh AG dapat meningkatkan perilaku kontak mata AG. Frekuensi kontak mata AG yang awalnya hanya sebanyak 5\%, yaitu $0-1$ kali dalam 10 kali percobaan meningkat menjadi $75 \%$ atau sekitar 7-8 kali dalam 10 kali trial. Selain itu hasil follow-up menunjukkan bahwa perilaku kontak mata pada AG menjadi $80 \%$, yaitu 8 kali dalam 10 kali trial. Hal ini menunjukkan bahwa efek pemberian intervensi stabil meskipun intervensi tidak lagi dilakukan.

\section{SARAN}

Pada penelitian selanjutnya disarankan supaya jumlah responden lebih dari satu sehingga program dapat digeneralisasikan untuk berbagai usia dan level dari autisme. Selain itu pada penelitian selanjtunya disarankan untuk mengikutsertakan orangtua atau pengasuh dalam pelaksanaan intervensi supaya program intervensi lebih optimal dan dapat digeneralisasikan dalam setting sehari-hari. Perlu dipertimbangkan juga pemberian aktivitas yang menarik bagi anak dan reinforcement yang menarik bagi anak. Aktivitas dan reinforcement yang menarik bagi anak dapat mendorong anak melakukan perilaku kontak mata. Selain itu, akan lebih baik jika dilakukan intervensi tambahan selain pelatihan kontak mata, misalnya pelatihan joint attention, komunikasi, dan interaksi sosial.

\section{DAFTAR PUSTAKA}

American Psychiatric Association. (2013). DSM-5 Diagnostic and Statistical Manual Of Disorder Fifth Edition . Washington: American Psychiatric Publising.

Autism Speak. (2018). CDC increases estimate of autism's prevalence by 15 percent, to 1 in 59 children. Diakses dari https://www.autismspeaks.org pada 31/08/2018 pukul 13.00 WIB.

Begeer, S., Rieffe, C. A., Termorgt, M. M., \& Stockmann, L. (2006). Attention to facial emotion expressions in children with autism. The National Autistic Society, 37-51.

Bondy, A. \& Frost, L. (2001). The picture exchange communication system. Behavioral Modification, 25 (725).

Carbone, V. J., O’Brien, L., Sweeney-Kerwin, E. J., \& Albert, K. M. (2013). Teaching Eye Contact to Children with Autism A Conceptual Analysis and Single Case Study. Education and Treatment of Children, 36, 139-159.

Dawson, G., Toth K., Abbot, R., Osterling, J., Munson, J., Estes, A., Liaw, J. (2004). Early Social Attention Impairments in Autism: Social Orienting, Joint Attention, and Attention to Distress. Developmental Psychology, 40 (2), 271283. 
Gutstein, S.E., Burgess, A.F., \& Montfort, K. (2007). Evaluation of the Relationship Development Intervention program. Autism, 11(5), 397-411.

Kazdin, A.E. (2013). Behavior modification in applied settings $\left(7^{\text {th }}\right.$ ed.). Illinois: Waveland Press.

Kennedy, M., Shawn, M. A. (2008). Eye Contact and Autism, American Journal of Nursing, 108 (11).

Lindgren, S., Doobay, A. (2011). Evidence based interventions for autism spectrum disorders, The University of Lowa.

Mangunsong, F. (2009). Psikologi dan Pendidikan Anak Berkebutuhan Khusus Jilid I. Jakarta: Lembaga Pengembangan Sarana Pengukuran dan Pendidikan Psikologi (LPSP3) Kampus Baru UI, Depok.

Mash, E. J., \& Wolfe, D. A. (2010). Abnormal Child Psychology fourth edition. USA: Wadsworth Cengage Learning.

Miltenberger, R. G. (2012). Behavior modification (principles and procedures) fifth edition. USA: Wadsworth Cengange Learning.

World Health Organization. (2018). Autism Spectrum Disorders. Diakses dari http://www.who.int/ pada 31/08/2018 pukul 13.00 WIB. 